Papexs and Proceedings of the Royal Society of Tasmania, Volume 114, 1980.

(ms. received 24.4 .1979$)$

\title{
EROSION AND RABBITS ON MACQUARIE ISLAND: SOME COMMENTS
}

by B.J. Griffin

Geology Department, University of Tasmania

(with one plate)

ABSTRACT

GRIFFIN, B.J., 1980 (31 V): Erosion and rabbits on Macquarie Island: some comments.

Pap. Proc. R. Soc. Tasm. 114: 81-83 (incl. one plate). ISSN 0080-4703.

Department of Geology, University of Tasmania, Hobart, Tasmania, Australia.

Rapid emergence and subsequent glacial and periglacial action on Macquarie Island have placed it in a state of high erosional activity. The dominant processes are mass erosion through landslips, soil creep slumping and solifluction. Fluvial and aeolian erosion are only important in very restricted areas. Rabbit activity has had a minimal effect on the overal. rates of erosion although appearing significant in some localised areas.

\section{INTRODUCTION}

Macquarie Island is widely recognised as an extremely interesting area in terms of most natural sciences. This brief report looks at erosion processes on the island and the effects of the rabbit population on these processes and their rates of operation. the $34 \mathrm{~km}$ by $3 \mathrm{~km}$ island lies almost midway between the Australian mainland and the Antarctic continent, and is a subaerial exposure of the Macquarie Ridge. Physically it is dominated by a $200-300 \mathrm{~m}$ high plateau bounded by very steep slopes and cliffs with only very minor low-lying coastal terraces. These raised marine terraces are of middle to late Holocene age, indicating an average uplift rate of the island between 1.5 and $4.5 \mathrm{~m}$ per 1000 years (Colhoun and Goede 1973).

Geologically Macquarie Island is at present considered to represent Miocene oceanic crust generated in a spreading ridge environment (Varne and Rubenach 1972). The northern tip and southern three-quarters of the island are composed of basaltic pillow lavas and associated dolerite dykes. The remaining northern quarter is composed of more massive units of coarser-grained gabbros and ultramafic rocks.

The Colhoun and Goede (1974) have shown that former ice action on the island was dominated by local plateau, valley and cirque glaciers which covered, at their maximum extent, some $40 \%$ of the island, rather than by complete over-riding of an easterly moving ice sheet (Mawson 1943). Present landforms are dominantly of former periglacial and glacial origin. The current climatic conditions are humid periglacial.

\section{PREVIOUS STUDIES OF EROSION}

Few observations have been made of erosion processes on Macquarie Island. However various workers in other disciplines have made some brief comments. Taylor (1935) suggested that rabbit grazing is having catastrophic effects, in terms of erosion, on the grassland areas of Macquarie Island. This view was strongly supported by Costin and Moore (1960). They suggested that on the steeper slopes, which include grassland slopes in excess of $70^{\circ}$ up to an altitude of $300 \mathrm{~m}$, elimination of the stabilizing dominants, Poa foliosa and Stizbocampa polaris, by rabbit grazing will almost certainly increase the incidence of minor landslips, resulting in the stripping of blanket bog peats and the development of screes. They finally suggested that small landslips in otherwise intact slopes often initiate an irreversible trend towards soil loss. 


\section{CURRENT OBSERVATIONS AND DISCUSSTON}

Soil creep is the major erosion mochanism on Macquarie Island. This is a continuous process with material gradually moving downslope under gravity. on Macquarie Island the soil-rock interface is permanenty saturated; a result of the continuous heavy drizzle and low mist that characterise the weather conditions on the island. Precipitation is rarely heavy and many of the water chamels on the island today are relict meltwater channe1s which are generally underfit (Colhoum and Gode 1974). Con sequently today fluvial erosion does not play a major role on Macquaric Island.

The most spectacular form of mass movement, nanely landslips, are very common on Macquarie Island. This is not surprising because the mass movement mante is in a permanent state of instability and only requires a suitable trigger to move more rapidly as a landslip. During tho three months $1975 / 76$ sumer field season it was observed that a number of landsips occurred inmediately after the heaviest rainfall period of the sumer. This correlation of landslips occurring after heavy rain periods has also been observed subsequently (G. Copson, pers. comm.). Nnother recognised trigger is large earthquakes and as Macquarie Island is seismically very active, earthquakes as we11 as heavy rain periods form the major triggers for the landslip activity. The irreversible soil loss trend after landslips suggested by costin and Moore (1960) has not been observed by the author. On most of the slopes on both coasts it is possible to see landslip areas in various stages of revegetation (plate la). Bare rock is only exposed, if at a11, at the head of the slip and this is quickly covered by collapse of upslope material.

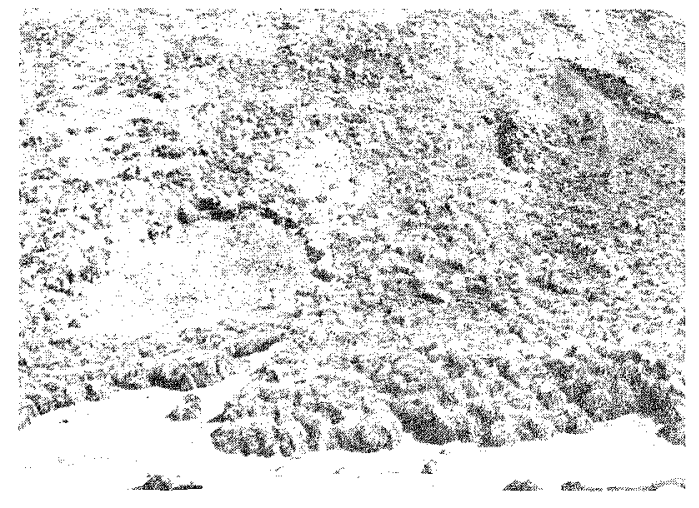

PLATE 1a. - Recent and revegetated landslips on steep coastal tussock slopes near Nuggets point at the northern end of Macquarie is land.

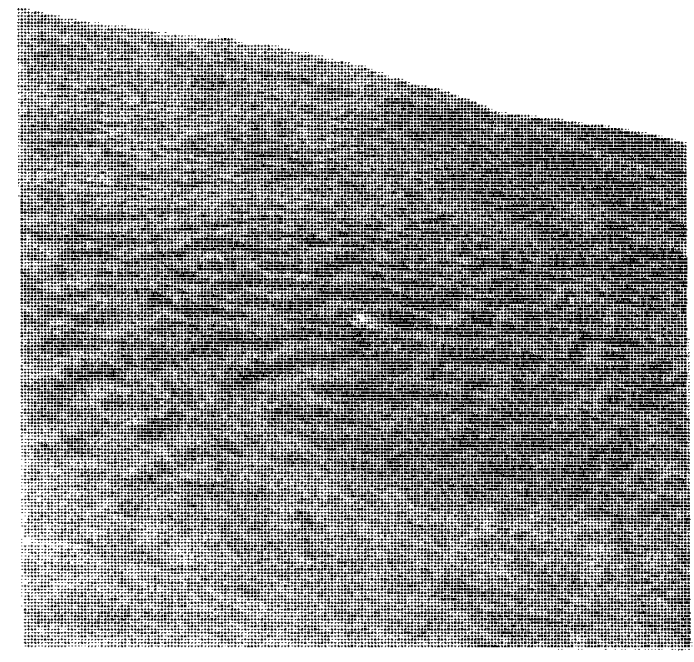

PLATE 1b... 'Terracettes on a grassed hilislope. 
Many of the grassland slopes contain small terraces or terracettes (plate 1b). These are commonly misnamed "sheep tracks" throughout rural mainland Australia and on Macquarie Island some workers have similarly misinterpreted these features as due to rabbit tracks or squats. Actually these features are usually a result of creep processes, solifluction and or occasionally small scale slumping.

Wind is another erosive agent on Macquarie Island; during the three month $1975 / 6$ summer the average wind speed was $26 \mathrm{~km}$ per hour. However because of the moist surface environment wind deflation effects are drastically reduced relative to those in drier environments. Moist clay has strong interparticle adhesion so that only during the rare dry periods if ever, are the clays deflated. Coarser material is more susceptible and fossil aeolian dunes deposited along the natural wind 'funnel' between Sandy Bay on the east coast and Bauer Bay on the west coast are being eroded through wind deflation. Observations suggest that this was initiated by rabbits burrowing on the windward side of the dumes. Erosion of raised marine ridges on the coastal terraces is probably also a result of similar rabbit activity. These areas are very small relative to the whole island and insignificant in terms of the overall erosion processes.

It has also been suggested that rabbits have increased the incidence of landslips by weakening an area through burrowing. No evidence has been presented on this and a visual comparison of the island today with photographs taken at about the time of introduction of rabbits would suggest that the rate of occurrence has not significantly altered. Furthermore areas of burrowing petrel colonies, which have a higher burrow density than rabbits, are not obviously more eroded than adjacent areas.

In summary, the major processes active on Macquarie Island are various forms of mass movement. Although rabbits may have severe botanical effects on the ecology, they have had little effect on the erosion of Macquarie Island. It is invalid to compare Macquarie Island with mainland Australia because of the major climatic differences and such comparisons are misleading.

\section{ACKNOWLEDGEMENTS}

Many people have provided fruitful discussion and advice on this topic, in particular Mr. G. Copson, Dr. E. Colhoun and Dr. J. Jenkins. Mr. G. Copson is thanked for supplying the photographs. The National Parks and Wildlife Service of Tasmania, the Australian Antarctic Division and the University of Tasmania have provided logistic support and funding for two visits to the island and this is gratefully acknowledged.

\section{REFERENCES}

Colhoun, E.A., and Goede, A., 1973: Fossil Penguin Bones, ${ }^{14} \mathrm{C}$ Dates and the raised marine terraces of Macquarie Island: some comments. Search, 4(11): 499-501.

1974: A reconnaissance survey of the glaciation of Macquarie Island. Pap. Proc. R. Soc. Tasm., 108: 1-19.

Costin, A.B., and Moore, D.M., 1960: The effects of rabbit grazing on the grasslands of Macquarie Island. J. Ecol., 48: 729-732.

Cumpston, J.S., 1968: Macquarie Island. ANARE Soientific Reports, Sexies A, 93.

Mawson, D., 1943: Macquarie Island: its geography and geology. Australasian Antarctic expedition 1911-1914 Scientific Reports, Series A, 5.

Taylor, B.W., 1955: l'he flora, vegetation and soils of Macquarie Island. Australian National Antarctic Research Expedition Reports, Series B., 11.

varne, R., and Rubenach, M.S., 1972: Geology of Macquarie Island and its relationship to oceanic crust. Amer. Geophys. Union, Antarctic Research Series, 19: 251. 